\title{
Architectural Analysis of a Triassic Fluvial System: the Sherwood Sandstone of the East Midlands Shelf, UK
}

\author{
OLIVER J. W. WAKEFIELD ${ }^{1,2}$, EDWARD HOUGH ${ }^{1}$, ALEX W. PEATFIELD²
}

1 - British Geological Survey, Keyworth, Nottingham, NG12 5GG, UK. Email: oliverw@bgs.ac.uk (corresponding author)

2 - Earth Sciences and Geography, Keele University, Staffordshire ST5 5BG, UK

\begin{abstract}
The Sherwood Sandstone Group of the northeast UK (East Midlands Shelf) has hitherto never been studied in detail to ascertain it's palaeoenvironment of deposition, largely because it is poorly exposed. As such, this paper aims to provide the first modern sedimentological interpretation of the Sherwood Sandstone in the east of England based on a field outcrop at the disused quarry at Styrrup. This is in stark contrast to the western parts of England where the Sherwood Sandstone is well exposed and offshore in the North Sea Basin where it is represented by a substantial library of core material where it is also relatively well understood. The outcrop at Styrrup Quarry allows contrasts to be made with the style and expression of the Sherwood Sandstone between eastern and western England. Specifically, this highlights differences around the variation in fluvial discharge (between lowstand and highstand) and the absence of aeolian facies types. It is interpreted that these differences relate to discharge variations between ephemeral and perennial systems with a perennial model proposed for Styrrup Quarry. This model draws upon inferences of additional water input from more local areas, likely topographic uplands of the London-Brabant and Pennine Highs which supplement the primary source of the Variscan Mountains in France with additional water and sediment.
\end{abstract}

Keywords: Triassic, fluvial, braided, ephemeral, perennial

\section{Introduction}

The Sherwood Sandstone Group is of great importance in the UK for a number of applied, including economic, reasons: $i$ ) it is one of the largest producing aquifers in the country (Allen et al., 1997), with groundwater being exploited for is use in agricultural and industrial practices in addition to a potable supply, ii) the unit is actively mined as both a source of aggregate and sandstone for the construction industry, iii) the interval is hydrocarbon producing in the East Irish Sea Basin (Meadows and Beach, 1993b), iv) the lateral equivalent within the North Sea Gas Province - the Bunter Sandstone Formation - have produced 5.5 tcf of gas ( $12 \%$ of gas 
produced to date; Gray, 2014), and, v) the Sherwood Sandstone underlies numerous urban centres (including Nottingham, Doncaster, York and Middlesbrough) which are at risk from a legacy of historic industrial contamination (Hough et al., 2006). Given the range and importance of the applications for the Sherwood Sandstone Group there currently exists a gap in our knowledge over the detailed internal composition of the facies and architectural elements within the group and any heterogeneity arising from them. This is most keenly felt in the north-eastern locations of the Sherwood Sandstone (separated from the western areas by the topographic high of the Carboniferous Pennines, and from south-western areas by a basement high between Charnwood and Nottingham; Fig. 1) where a lack of good-quality outcrop hampers characterisation, including even attempts at formational sub-division of the Group. It is however not necessarily appropriate to supplement a lack of understanding in north-eastern England with the comparatively well exposed Sherwood Sandstone in western England as there are known spatial variations in character between them (Barnes et al., 1994). For example, there are readily identifiable differences in the depositional environments, including; i) an absence of identified aeolian facies in the eastern Sherwood Sandstone contrasting the mixed aeolian-fluvial formations of the group in the north-east of England (Cowan, 1993; Mountney and Thompson, 2002; Bloomfield et al., 2006), and ii) an absence of well-developed/regionally pervasive palaeosols (pedogenic processes) in the eastern parts of England compared to western and southern.

As such, there is a requirement to better understand the spatial variations in the Sherwood Sandstone with examples pertaining to each region. Such outcrop driven studies will provide data and application at a resolution beyond geophysical techniques for applications where direct observation is not always possible, i.e. reservoir characterisation. An understanding of the sandstone strata that places it in a modern sedimentological context that describes the internal heterogeneity could be up-scaled and used to parameterise models using a prediction of sandbody geometry will be relevant to a wide user community.

Deposition of the Sherwood Sandstone Group in central Britain is ascribed to a terrestrial mixed fluvial and aeolian environment that resulted in a sandstone-dominated succession with minor amounts of mudstone that accumulated in perennial and ephemeral water bodies (Cowan, 1993; Mountney and Thompson, 2002; Bachmann et al., 2010; Ambrose et al., 2014). Although the Sherwood Sandstone Group has been the focus of numerous previous studies throughout the UK and offshore (Warrington, 1970; Benton et al., 2002; Hounslow and Ruffell, 2006) there are relatively few descriptions of the Group on the east Midlands Shelf. Where published, research within this area has primarily been focussed on the applications related to groundwater extraction and contaminant transport (e.g. Bath et al., 1987; Green, 1989; Smedley and Edmunds, 2002). Diagenesis and deformation are also important aspects when 
understanding the petrophysical properties of aquifers or hydrocarbon reservoirs, but these secondary processes are influenced by the primary sedimentology of the host rock. For instance at Styrrup Quarry, McKinley et al. (2013) has linked diagenetic processes (secondary processes) to specific architectural elements (primary depositional). Indeed such facies control on deformation is also widely acknowledged (Fossen et al., 2007). This implication of primary sedimentary control/influence on secondary processes only validates more the need to address the relatively little work conducted to characterised the sedimentology of the group beyond its primarily fluvial origin (Warrington et al., 1980) and address this gap in our knowledge.

\section{Geological Setting}

The onset of redbed sedimentation during the Permo-Triassic of Britain defines a transition from shallow marine and carbonate platform sedimentation during the Kazanian - Tatarian to continental deposition of the Induan - Olenekian. During the Lower Triassic, Britain lay at a palaeolatitude of approximately 20 degrees north, within the Pangaea supercontinent (Ziegler, 1988). The Southern Permian Basin developed in response to crustal extension during initial stages of the break-up of Pangaea (Ziegler, 1988). The basin is characterised by east-west extension and some associated syn-depositional faulting has been speculated (Leeder and Hardman, 1990). This broad area of sediment accumulation stretched across much of northwest Europe towards modern-day Poland (Doornenbal and Stevenson, 2010). In the western part of the basin, northwards-draining fluvial systems developed, supplying vast quantities of sediment derived from the American and Variscan highlands located approximately $600 \mathrm{~km}$ to the south, in present-day northern France (McKie and Williams, 2009). The East Midlands Shelf is located on the northern margin of the London-Brabant structural high, a regional platform that bounded the southern Permian Basin from highlands to the south and west, and represents a restricted sub-basin in the western part of the Southern Permian Basin. In contrast to the much smaller part fault-bounded Permo-Triassic basins to the west (e.g. Cheshire, Stafford, Needwood), the East Midlands Shelf is characterised by be fanning geometries and pinch-outs onto highs rather than faulted stratigraphic relationships.

The accumulation of Early Triassic sediment preserved on the East Midlands Shelf has been assigned to the Sherwood Sandstone Group. This crops out between Nottingham (Nottinghamshire) in the south and Darlington (North Yorkshire) in the north, and extends eastwards beneath a cover of younger Mesozoic rocks, where it becomes contiguous with the Bunter Sandstone of the Southern North Sea. Subsidence rates during the deposition of Sherwood Sandstone on the East Midlands Shelf are unknown though they are considered to have been relatively constant and of sufficient rate for the accumulation of thick $\sim 200-300 \mathrm{~m}$ 
thick of fluvial succession of the Sherwood Sandstone in areas like Nottingham, where the fluvial expression is indicative of constant subsidence rates (cf. Howard et al., 2009).

The Sherwood Sandstone Group (sensu Ambrose et al., 2014) is characterised by an accumulation of arenaceous sandstone, pebbly sandstone and subordinate breccioconglomerates and mudstone that range in thickness up to $450 \mathrm{~m}$ thick in eastern England (e.g. Berridge and Pattison, 1994; Gaunt, 1994). Age-diagnostic fossils within this succession are rare, resulting in difficulties associated with the chronostratigraphic subdivision and correlation of the group (Jeans, 2006), although the imprint of broader climatic changes results in gross variations in sedimentary character that can be regionally correlated (Smith et al., 1974) and confirmed by the response on down-hole geological logs. The Group is part of the siliciclastic Permo-Triassic New Red Sandstone Supergroup, which preserves multiple intervals of continental fluvial and aeolian deposition. The Sherwood Sandstone in eastern England overlies the Permian Lenton Sandstone, which itself represents a transition from fluviatile to aeolian sedimentation (Howard et al., 2009); where the Lenton Sandstone is not present, the Sherwood Sandstone overlies marine mudstones of the Roxby Formation. Overlying the Sherwood Sandstone, the Mercia Mudstone, deposited during a transgression from estuarine shales followed by sabkha-style sedimentation across a coastal plain as the Southern Permian Basin filled (Doornenbal and Stevenson, 2010).

Formal subdivision of the Sherwood Sandstone is based predominantly on the presence or absence of extra-formational pebble content (see Ambrose et al., 2014), with little regard to acknowledge the primary depositional facies.

Published reviews of the Permo-Triassic succession of the East Midlands Shelf are given by Kent et al. (1980) and Aitkenhead et al. (2002). More regional syntheses are available (e.g. Wills, 1970; Doornenbal and Stevenson, 2010).

\section{Data Collection and Field site}

The Sherwood Sandstone on the East Midlands Shelf has been commercially exploited principally as a source of sand for use in construction aggregate. This has resulted in a number of quarry faces that provide discontinuous exposures that allow the sedimentology and architecture of facies elements of the Sherwood Sandstone to be observed. Styrrup Quarry, located in the northern part of Nottinghamshire [460600 390000] (Fig. 2), exposes $5-8 \mathrm{~m}$ faces of sandstone in a quarry face that extends some $140 \mathrm{~m}$ laterally. The limits of the quarry extend beyond the dimensions stated but these cliff-lines are unfortunately of poor quality and heavily vegetated (Fig. 2). Mean palaeocurrent data from the outcrop at Styrrup is to the 
southeast, varying slightly from a more regional considered trend to the northwest (Ambrose et al., 2014).

Styrrup Quarry is located in the lower part of the Chester Formation (formerly the Nottingham Castle Sandstone; Fig. 3), approximately $15 \mathrm{~m}$ above the presumed junction with the Lenton Sandstone Formation. The strata exposed have been described previously (Kitching et al., 1977; Burley, 1984; McKinley et al., 2011; McKinley et al., 2013), and summarised in Benton et al. (2002), where the depositional setting of transverse barforms within a minor and major channels in a broadly northwards-draining major fluvial system was suggested.

The quarry at Styrrup would have originally exposed a length of $\sim 400 \mathrm{~m}$ of sandstone cliff lines with almost a complete $360^{\circ}$ configuration. However, of all these cliffs, a single very well exposed $140 \mathrm{~m}$ long and up to $8 \mathrm{~m}$ high section forms the basis of this work, where the other quarry faces are of generally poor quality with some forming as only as scree slopes.

Data collection comprises a single large architectural panel that covers approximately $\sim 1400 \mathrm{~m}^{2}$ (Fig. 4). The architectural panel has a long $\sim 110 \mathrm{~m}$ section broadly orientated NNWSSE with a southern $\sim 30 \mathrm{~m}$ orientated broadly perpendicular, ENE-WSW. The architectural panel details the constituent architectural elements of the cliff there geometry and relationship to one another. Four sedimentological logs (Fig. 5) were also conducted on the panelled section and their positions can be viewed in Fig. 4. Additionally palaeocurrent data was also obtained from a range of forsets types and sizes. These readings were normalised for a slight $\left(3-4^{\circ}\right)$ local structural tilt.

\section{Facies and Architectural Elements}

For the sake of brevity the description and interpretation of the ten lithofacies can be viewed in Table 1, additionally photographic examples of the different lithofacies are included in Fig. 6.

Five architectural elements are recognised and a brief description of each, including constituent facies types, is provided in Table 2. The following sections describe the same architectural elements in greater detail, and the nomenclature as devised by Miall $(1996 ; 2014)$ is used.

\subsection{Lateral accretion element - LA}

Description. Wedge to lensoidal shaped elements that have a thickness of $1-2 \mathrm{~m}$ and measured lateral extents $10-18 \mathrm{~m}$. Component lithofacies include facies $\mathrm{Sp}$ (planar crossbedded sandstone), St (trough crossbedded sandstone), Sh1 (upper plane-beds) and Sr (ripple-laminated sandstone; Table 1). The azimuth of inclined surfaces from facies Sp and St 
are highly variable (constituting a range from $351^{\circ}-173^{\circ}$ ) and occur both perpendicular to, and congruent with, the prevailing measured drainage direction. Some examples of crossbedding in this element appear with a sigmoidal shape whereby the foresets show an asymptotic base and top and are arranged in a toplap, offlap and downlap relationship with the adjacent beds. Some of these crossbeds show a component of vertical thickening where adjacent asymptotic topsets of individual beds extend and cap numerous adjacent (toplap).

The base of this element may contain pebble intraformational and extraformational clasts of quartz and mudstone and in rarer examples, these facies are also observed higher up within the element on some of the steeper inclined coset surfaces. Sparse examples of crosslaminated sandstone (facies $\mathrm{Sr}$ ) interdigitated with horizontally laminated sandstone (facies Sh1) are observed at the upper portions of some elements, though this is often poorly defined and more commonly partially removed by overlying erosively based units. Where facies Sh1 and $\mathrm{Sr}$ are present it overlies facies $\mathrm{Sp}$ and $\mathrm{St}$ with a first-order bounding surface. Palaeocurrent readings from facies Sr have an average flow direction to the $128^{\circ}$.

This element contains numerous examples of first-order surfaces within set boundaries that truncate multiple cross-stratum of facies Sp and St. Additionally larger sharp inclined surfaces dip concordant with the present cross-strata but at lower angles $\left(8-12^{\circ}\right)$. These surfaces truncate multiple individual sets bounding surfaces and often extend in an inclined fashion from the top to the base of the element.

Interpretation. This element represents bedforms that underwent lateral growth with lesser extent of down-stream (Bridge, 1993; Bridge et al., 1995; Ghazi and Mountney, 2009; Grenfell et al., 2012). Lateral accretion may have occurred coeval with downstream accretion or may have resulted from periods of falling-stage flow where flow conditions promoted the margins of the bedforms to laterally accrete. Examples where this element comprises rounded (sigmoidal) trough crossbeds are interpreted as larger bedforms that experienced a more continual component of lateral accretion. The more complete and regular spaced beds of such foresets likely reflects the more constant lateral growth of bed-forms associated with differential flow velocities of water on the outside of a sinuous path (Olsen, 1988) rather than an ephemeral effect of falling-stage conditions.

The presence of facies Sr and Sh1 at the upper portions of this element indicates subaqueous flow over some of the bedforms. Variations between the deposition of facies Sr and Sh1 result from variations between upper and lower regime conditions, possibly reflecting subtle changes in water depth and or velocity linked to discharge variability. 
The observed instances of first-order surfaces truncating cross-strata within individual sets are likely reactivation surfaces and likely represent more local changes in flow conditions. Larger observed surfaces are interpreted as third-order erosive surfaces within the larger bedforms, and probably relate scour associated with falling stage flow conditions (Bristow and Best, 1993).

\subsection{Channel element $-\mathrm{Ch}$}

Description. Erosively based ( $5^{\text {th }}$ order surface) ' $u$ ' shaped elements (in sections perpendicular to palaeoflow) that have measured lateral extents where continuity of outcrop allows of at least $20 \mathrm{~m}$ and a thickness of $1-3 \mathrm{~m}$. Compositional facies types of Spb (pebbly sandstone), St, Sh1 and Sm (massive sandstone) can sometimes individually and collectively show a crude upward-fining character, with gravel clasts (facies $\mathrm{Spb}$ ), if present, forming as the basal constituent facies type; often overlain by trough crossbedded sandstone (facies St). Facies St is commonly overlain by facies Sh1 and in rare examples this can be subsequently overlain by ripple cross-laminated sandstone (facies $\mathrm{Sr}$ ) which grades vertically from facies Sh1. Such complete successions are rarely preserved and the top part of the successions are frequently locally removed due to the erosive cross-cutting nature of the lateral and vertical stacking of such multi-storey erosively based elements. The pebble content of this element is often observed forming at the base of individual trough crossbedded sets and isn't always restricted to the basal facies component (e.g., facies Spb). These pebbles are primarily of rounded quartz composition but other clasts including locally derived thin $(\sim 0.5 \mathrm{~cm}$ thick) smears of red-brown mud and rare examples of limestone are also observed. Much larger examples of mud clasts (mud 'cobbles') are also observed at the base of this element type and photographic examples are presented in Fig. 7. Some elements of this type have a basal component of facies Spb that forms as laterally restricted $(0.1-0.4 \mathrm{~m}$ wide) isolated lenses that doesn't always encompass the entire flatter (near horizontal) lower portions of the erosive bounding surface.

Interpretation. This element is interpreted to represent erosively based channel elements (Bridge, 1993; Gibling, 2006; Bridge and Lunt, 2009), with the presence of facies St recording the migration of smaller sinuous crested bedforms. Palaeocurrent measurements from trough crossbeds have a mean azimuth of $162^{\circ}$ in keeping with the local broad south-easterly palaeodrainage direction. Basal pebble intraclasts overlying the erosive lower bounding surface of the element (base of channel) are interpreted to represent channel lag deposits formed in initial high flow conditions. Isolated examples of facies Spb may reflect deposition from the thalweg in a channel where the prevailing flow energy (apart from the thalweg) was insufficient to entrain larger pebble material. 
Where the succession includes facies type Sh1 it records a progression from lower to upper flow regime with the deposition of upper plane beds (Cheel and Middleton, 1986). Indeed the observed constituent facies type and the vertical succession, where complete, detail a gradual infilling of the eroded channel under progressively low energy conditions.

The observed mud cobbles and their size suggest that the material was derived from the immediate vicinity to the channels to have remained so relatively complete. However, no such sufficiently mud-rich units are identified at Styrrup Quarry, suggesting perhaps that the source overbanks have a very low preservation potential and were likely extensively reworked or removed. The presence of intraclasts of limestone is likely resulting from the Carboniferous sediments exposed in the Pennine High.

\subsection{Downstream accreting element - DA}

Description. Lensoidal shaped element with constituent facies Spb, St, Sp and Sh1 though facies Sp, St and SI (low-angle sandstone) account for $>80 \%$ by volume of the element. Lowangle and planar and trough crossbedded facies occur in sets $0.4-2.2 \mathrm{~m}$ thick that exhibit lateral and vertical stacking in to cosets that have lateral extents up to $40 \mathrm{~m}$ and can attain thickness of up to $2.6 \mathrm{~m}$. Individual sets are bounded by first-order set boundaries and cosets are bounded by second-order coset bounding surfaces. Erosively-based coset bounding surfaces ( $3^{\text {rd }}$ order surface) down-cut and truncate underlying sets of crossbedding with the surface commonly orientated at low angle in a broadly downstream orientation. Numerous higher-angle $\left(20-25^{\circ}\right)$ surfaces are observed within set boundaries and these truncate individual cross-strata within the sets.

The boundaries of the element are defined commonly by the coset surfaces ( $2^{\text {nd }}$ order) with the lower bounding surfaces commonly containing mudstone and extraclasts of quartz. In rare examples the toesets of individual cross-strata become indistinct as they grades into thin (5-11 cm thick) pebbly sandstone layers (facies $\mathrm{Spb}$ ) down-dip defining a $3^{\text {rd }}$ order surface.

The southern section of outcrop, orientated broadly perpendicular to the palaeodrainage direction, shows that the crossbedding with this element type are commonly dominated by low-angle crossbedding (facies $\mathrm{Sp}$ ) at the margins; becoming progressively lower angle towards those lateral margins. Rare examples of horizontally bedded sandstone (facies Sh1) are observed restricted to the uppermost portions of this element. Where this is observed they occur as thin $(<0.2 \mathrm{~m})$ units that cap the element. Very crudely formed small ripple-forms are also observed in such instances.

Interpretation. This element represents the migration of complex bedforms in a downstream direction (Rust, 1972; Miall, 1977; Dalrymple and Rhodes, 1995). The coset bounding surfaces 
are indicative of the migration of larger 2D barforms with smaller sets of facies $\mathrm{Sp}$ and $\mathrm{St}$ $(0.1-0.3 \mathrm{~m})$ indicative of smaller $2 \mathrm{D}$ and $3 \mathrm{D}$ mesoforms (respectively) migrating in front of, or on the larger macroforms (Miall, 1988; Bristow and Best, 1993; Ghinassi, 2011). Successions of vertically stacked sets separated by first-order surfaces record trains of dunes (mesoforms) moving over barforms (macroforms) (Walker and Cant, 1984; Miall, 2014). Reactivation surfaces ( $2^{\text {nd }}$ order surface) are identified within individual sets and these reflect minor erosion events likely associated with bedform realignment due to small fluctuations in flow rate and direction (cf. Røe and Hermansen, 2006). Flow variation for the smaller migrating bedforms could be a product of localised adjustment of the current associated with the proximity of the larger interpreted barforms. Alternately, erosively based coset surfaces could relate to similar flow variability and realignment of the larger barforms, or could relate to the frontal scour associated with the re-attachment point of the flow-line beyond the barform brink (Nichols, 2009).

The presence of facies Sh1, representing upper plane beds, indicates that the barforms were likely subject to subaqueous conditions during high flow stage events; whether these conditions prevailed constantly is not known. The lack of observation of facies Sh1 in all interpreted downstream accreting elements could relate to: i) removal of the upper plain beds by subsequent migrating bars and bedforms, ii) removal during periods of low, or high-flow stages, or, iii) that conditions pertaining to the deposition of upper plane beds (upper flow conditions) didn't exist on all interpreted barforms.

\subsection{Chute channel - Cch}

Description. Erosively based ( $4^{\text {th }}$ order surface) ' $u$ ' shaped elements with a lateral extent from $1.2-2.6 \mathrm{~m}$ and thicknesses $\sim 0.5 \mathrm{~m}$. The observed ' $\mathrm{u}$ ' shaped geometry of the element is relatively symmetric, a well-preserved example shown in Fig. 8. Constituent facies types include from base to top small-scale $(0.3-0.4 \mathrm{~cm}$ thick) examples of predominately troughcrossbeds (facies St) some minor inclusion of planar-crossbedding (facies Sp), overlain by variably observed instances of horizontally bedded sandstone (facies Sh1). Some of the elements have a basal bounding surface that is directly overlain by scattered pebbles of quartz, though this isn't always preserved.

Interpretation. This element is interpreted as the cut and establishment of a small chute channel during high discharge/flood stage conditions (Blum et al., 1994; Grenfell et al., 2012). The dimension of the observed chute channels are concordant with Ghinassi's (2011) 'type 1' chute channels. Indeed the largely symmetric cross-section of the channels suggests that they have a linear (low-sinuosity) morphology. Pebbly basal extraclasts likely represent small channel lag deposits resulting from bedload tractional conditions (Nemec and Postma, 2009). 
The presence of the lateral accretion elements suggest the course of the river system was in part sinuous enough to promote the cutting of more efficient channels for the discharge of water, i.e. straighter channels. The formation of chute channels likely occurred in response to the forcing of water over barform tops during periods of higher discharge, generating the energy required to incise the smaller channel feature through existing barforms (Peakall et al., 2007; Grenfell et al., 2012).

\subsection{Sandy floodplain (overbank) - SF}

Description. Comprises highly discontinuous tabular elements of horizontally laminated and bedded sandstone (facies Sh2) Laminated mudstone (facies FI) and cross-laminated sandstone (facies Sr). Where outcrops allows this element has a lateral extent of up to $20 \mathrm{~m}$ and a thickness that varies from $0.1-3 \mathrm{~m}$. This element commonly comprises of fine- and very-fine sandstone and in rare cases very thin ( $3-4 \mathrm{~cm}$ thick) layers of laminated mudstone. In many examples, this element is locally eroded by numerous other element types and as such typically forms as discontinuous tabular-like bodies.

Small-scale upward-fining sequences within the horizontal bedding and lamination are observed. In some examples, the more readily evident of these show a very slightly erosive surface ( $4^{\text {th }}$ order) that cuts underlying horizontal lamination/bedding (erosion on a sub-cmscale). Small ripple forms can be identified within this element though they are often poorly developed; some isolated small highly round pebbles of quartz and purple-red sandstone are also present.

Within this element, numerous examples of facies Sh2 are observed with a pale-coloured mottling. This mottling occurs as white to white-green circular or oval isolated patches of sandstone and compositionally and structurally appears similar to the rest of the facies. The more oval instances of this element show a vertical trend to the long axis of the mottling oval.

Interpretation. This element is interpreted as overbank deposition on a sandy floodplain (Sadler and Kelly, 1993; Bristow et al., 1999; Stanistreet and Stollhofen, 2002; Fisher et al., 2007). The individual erosive surface and upward-fining units represent individual discrete flood events. The discrete flood events are the product of non-channelised discharge (crevasse splay) onto the surrounding proximal areas and the subsequent reduction in flow velocity and energy associated with non-channelised pervasive flow (Walling and He, 1998; Fisher et al., 2007). The presence of some isolated pebbles suggests that the flooding of the adjacent areas was of sufficient vigour at least initially to deposit coarser-grade material on the overbank before standing water conditions and deposition from settling occurred. The thin laminated mudstone component for this element is interpreted to represent the latter stages of settling from suspension. This mudstone component appears to have experienced 
perennial subaqueous exposure, and lacks evidence of drying indicators, though such instances would unlikely to be widely evident due to the small amount of finer-grained fraction for this element.

Observed instances of white-mottling are of an unknown origin. It was initially assumed that the white-mottling was the result of rhizolith development in the overbank areas; an expected feature where vegetation exploits available moisture in a semi-arid setting (Wakefield and Mountney, 2013). However, no calcified root structures or features indicating pedogenesis such rooting are observed at Styrrup, although calcification and evidence of colonization has been described elsewhere in the Sherwood Sandstone (e.g. Bouch et al., 2006; Newell, 2006). Alternately, the mottling may have been caused by the deposition of isolated plant fragments which were incorporated and entrained in the flow. As such, the plant fragments could have originated from an overbank area upstream that differ in character compared to those identified in the Styrrup outcrop. The relatively sand-rich, mud-poor deposits of the floodplain identified likely reflects the overbank deposition from the sand-rich adjacent fluvial system (cf. Lewin and Ashworth, 2014) combined with the prevalence of arid and semi-arid regions to favour calcisol development over clay enrichment pedogenic processes (Cooke et al., 1993).

\section{Depositional Model and Discussion}

Fig. 9 represents a diagrammatic conceptual model for the observed palaeoenvironment for the outcrop at Styrrup Quarry. This model was created using architectural panel data (Fig. 4) based on the aforementioned architectural elements including their relationship to one another. The model proposed is that of a moderate-sinuosity sand-dominated braided river system. Channel fills with erosive bases are accompanied by lateral and mid-channel bar forms showing a mixture of lateral and downstream accretion. A braided river interpretation is concordant with observations by other authors for the lower part of the Sherwood Sandstone elsewhere in the UK and Ireland: Northwest England (Burley, 1984; Jones and Ambrose, 1994), East Irish Sea Basin (Cowan, 1993; 1993b; Meadows and Beach 1993a), Southern England (Holloway et al., 1989), Ireland (Schmid et al., 2004) and West Midlands (Steel and Thompson, 1983).

The identification of a braided system for the numerous parts (and locations) of the Sherwood Sandstone Group is likely a function of the variable discharge rates associated with fluvial systems in semi-arid and arid systems (Graf, 1988; Bullard, 1997; Bullard and Livingstone, 2002; Belnap et al., 2011; Harvey, 2011) and the tendency for such variable fluvial systems to have a braided morphology (Miall, 1977). This is also observed in other systems where variable discharge promotes braiding (Lesemann et al., 2010; Ashmore et al., 2011; Lee et 
al., 2015). As such, there is a reasonable expectation that braided rivers, especially those in arid and semi-raid settings, never achieve equilibrium conditions with their flow. Indeed, the evidence of reactivation surfaces (flow adjustment) and the establishment of chute channels suggest some relative variation in flow discharge. However, the nature of this variation is considered relatively small, with evidence suggesting that the river was potentially continuously flowing (perennial) for at least significant periods of time at Styrrup Quarry. This is significant when considering that the widely accepted source for the water and a good proportion of the sediment within the fluvial system was derived from the Caledonian Uplands (McKie and Williams, 2009) approximately $500-600 \mathrm{~km}$ away. This is not necessarily usual as it has been observed that fluvial systems in dryland settings (arid/semi-arid) can sometimes exhibit water levels higher than expected, with the water levels reflecting upstream conditions not necessarily within the arid setting (Miall, 1977; Bullard and McTainsh, 2003). However, given that the river must was flowing across multiple semi-arid basins to reach the Styrrup location suggests that the catchment must have had a significant input of water to have managed such a feat, and or, that supplementary amounts of water were added more locally. Indeed the variations between the preserved expression of the Sherwood Sandstone between east and west England suggest that more localised conditions must have had a controlling influence given the shared source in northern France.

A perennial interpretation is also supported by the complete absence of aeolian facies; notable when general environmental conditions are believed conducive to aeolian development. In western England the Sherwood Sandstone is observed interdigitating with aeolian and fluvial facies types where interpreted quiescence in the fluvial system promotes the flourishing of the coeval aeolian systems (Mountney and Thompson, 2002; Bloomfield et al., 2006). However, the continuous wet conditions of a more perennial fluvial system in the east of England may have retarded aeolian development through the capture and inhibiting of aeolian entrainment. The source of an additional source of water and sediment is likely from the London-Brabant High situated to the south, or the Pennine High situated to the west. Given that localised pebbly facies in the Sherwood Sandstone are identified fringing the Pennine High suggest that is was indeed shedding detritus and water into the system (Steel and Thompson, 1983). Provenance analysis of the sediment at Styrrup Quarry will be conclusive to this interpretation, though such a study was beyond the scope of this project.

This lack of preservation potential is likely the reason for the absence of the source sediment for the mud cobbles incorporated in the section. These mud cobbles by virtue of the cohesive strength of the material implies an immediate local source; a source that is not evidenced within the outcrop. This absence could be related to the limits of the outcrop, however, the 
Sherwood Sandstone exposed in Nottingham City where the exposure is generally very good also exhibit mud intraclasts without evidence of the source (Howard et al., 2009). Overbank elements as well as being devoid of mud material are also lacking any indication of pedogenesis or colonisation by vegetation. This is important as Gran and Paola (2001) note that during dry periods, both channels and floodplain areas may also be subject to increased pedogenic development, especially calcrete cementation, which may increase resistance to erosion and subsequently alter channel form (Huang and Nanson, 1998). However, calcrete development is also not observed within the outcrop or in the wider region, though significant amounts of calcrete are observed in southern parts of England (Newell, 2006); suggesting that the lower flow or dry periods noted by Gran and Paola (2001) may not be occurring supporting the hypothesis of a perennial flow regime. It is unusual however that given the interpretation of a more constant source of water in an arid/semi-arid environ that evidence of plant colonisation isn't prevalent. The authors consider this lack to be possibly related to; i) the removal of plant-rich overbanks during normal fluvial processes, ii) that conditions with the presence of water were still too restrictive for wide-spread plant colonisation and flourishing, and or, iii) that the Quarry at Styrrup is immediately within the braided system, and hence was most favourable to the quarrying of sandstone blocks. It is also conceivable (based on modern dryland systems) that overbank regions were subject to microbial crust development rather than plant colonisation (cf. Dickerson et al. 2013). However, despite conditions possibly being favourable to the growth of microbial communities no such evidence is also observed, perhaps suggesting that the outcrop did indeed occupy a position within the braid system.

\section{Conclusions}

The Sherwood Sandstone is very poorly exposed in the East Midlands Shelf and the outcrop at Styrrup Quarry represents the first opportunity to characterise the paleaoenivronment in detail for the area. As such, the Sherwood Sandstone exposed at Styrrup Quarry records the deposition of a moderately sinuous sand-dominated braided river system. The record fluvial system at Styrrup Quarry is interpreted to have been more perennial-like, this is based on; i) the lack of the establishment of aeolian facies, a result of water inhibiting wind entrainment, and, ii) the lack of evidence for lowstand flow conditions. Some variability within the fluvial system is however identified through the establishment of reactivation surfaces and the establishment of chute channel. The lack of observed instances of plant colonisation is possibly due to a number of features relating to, outcrop scale, inhospitable palaeoenvironment and anthropogenic selection to the most competent sandstone horizons. 


\section{Acknowledgements}

Edward Hough and Oliver Wakefield publish with the approval of the Executive Director of the British Geological Survey, Natural Environment Research Council. Steve Banham, Stuart Clarke, Joanne Thompson and Catherine Cripps are all thanked for their insightful comments and help in the construction of this work.

\section{References}

Aitkenhead, N., Barclay, W.J., Brandon, A., Chadwick, R.A., Chishilm, J.I., Cooper, A.H., Johnson, E.W., 2002. British regional geology: the Pennines and adjacent areas (Fourth edition). British Geological Survey, Nottingham.

Allen, D.J., Brewerton, L.J., Coleby, L.M., Gibbs, B.R., Lewis, M.A., MacDonald, A.M., Wagstaff, S.J., Williams, A.T., 1997. The physical properties of major aquifers in England and Wales, British Geological Survey Technical Report WD/97/34. Environment Agency R\&D Publication 8, pp. 312.

Ambrose, K.A., Hough, E., Smith, N.J.P., Warrington, G., 2014. Lithostratigraphy of the Sherwood Sandstone Group of England, Wales and south-west Scotland. British Geological Survey Research Report: 56.

Ashmore, P., Bertoldi, W., Tobias Gardner, J., 2011. Active width of gravel-bed braided rivers. Earth Surface Processes and Landforms, 36(11): 1510-1521.

Bachmann, G.H., Geluk, M.C., Warrington, G., Becker-Roman, A., Beutler, G., Hagdorn, H., Hounslow, M.W., Nitsch, E., Röhling, H.G., Simon, T., Szulk, A., 2010. Triassic. In: J.C. Doomenbal, A.G. Stevenson (Eds.), Petroleum Geological Atlas of the Southern Permian Basin Area. EAGE, Amsterdam.

Barnes, R.P., Ambrose, K., Holliday, D.W., Jones, N.S., 1994. Lithostratigraphical subdivision of the Triassic Sherwood Sandstone Group in west Cumbria. Proceedings of the Yorkshire Geological Society, 50(1): 51-60.

Bath, A.H., Milodowski, A.E., Strong, G.E., 1987. Fluid flow and diagenesis in the East Midlands Triassic sandstone aquifer. Geological Society, London, Special Publications, 34(1): 127-140.

Belnap, J., Munson, S.M., Field, J.P., 2011. Aeolian and fluvial processes in dryland regions: the need for integrated studies. Ecohydrology, 4(5): 615-622.

Benton, M.J., Cook, E., Turner, P., 2002. Permian and Triassic red beds and the Penarth Groups of Great Britain. Geological Conservation Review Series, 24: 337. 
Berridge, N.G., Pattison, J., 1994. Geology of the country around Grimsby and Patrington. Memoir of the British Geological Survey, Sheets 81, 82, 90 and 91 (England and Wales). Memoir of the British Geological Survey. H.M.S.O., London, 116 pp.

Bloomfield, J.P., Moreau, M.F., Newell, A.J., 2006. Characterization of permeability distributions in six lithofacies from the Helsby and Wilmslow sandstone formations of the Cheshire Basin, UK. Geological Society, London, Special Publications, 263(1): 83101.

Blum, M.D., Toomey III, R.S., Valastro Jr, S., 1994. Fluvial response to Late Quaternary climatic and environmental change, Edwards Plateau, Texas. Palaeogeography, Palaeoclimatology, Palaeoecology, 108(1-2): 1-21.

Bouch, J.E., Hough, E., Kemp, S.J., Mckervey, J.A., Williams, G.M., Greswell, R.B., 2006. Sedimentary and diagenetic environments of the Wildmoor Sandstone Formation (UK): implications for groundwater and contaminant transport, and sand production. In: R.D. Barker, J.H. Tellam (Eds.), Fluid Flow and Solute Movement in Sandstones: The Onshore UK Permo-Triassic Red Bed Sequence. Geological Society of London Special Publications, London, pp. 129-153.

Bridge, J.S., 1993. The interaction between channel geometry, water flow, sediment transport and deposition in braided rivers. In: J. Best, C.S. Bristow (Eds.), Braided Rivers. Geological Society Special Publication, pp. 13-71.

Bridge, J.S., Alexander, J., Collier , E.L., Gawthorpe, R.L., Jarvis, J., 1995. Groundpenetrating radar and coring used to study the large-scale structure of point-bar deposits in three dimensions. Sedimentology, 42: 839-852.

Bridge, J.S., Lunt, I.A., 2009. Depositional Models of Braided Rivers. In: G. Sambrook Smith, J.L. Best, C.S. Bristow, G. Petts (Eds.), Braided Rivers: Process, Deposits, Ecology and Management. International Association of Sedimentologists Special Publication, pp. 11-50.

Bristow, C.S., Best, J.L., 1993. Braided rivers: perspectives and problems. Geological Society, London, Special Publications, 75(1): 1-11.

Bristow, C.S., Skelly, R.L., Ethridge, F.G., 1999. Crevasse splays from the rapidly aggrading, sand-bed, braided Niobrara River, Nebraska: effect of base-level rise. Sedimentology, 46(6): 1029-1047.

Bullard, J.E., 1997. Vegetation and dryland geomorphology. In: D.S.G. Thomas (Ed.). Arid Zone Geomorphology: Processes, Form and Change in Drylands. Wiley, Chichester, pp. 109-131.

Bullard, J.E., Livingstone, I., 2002. Interactions between aeolian and fluvial systems in dryland environments. Area, 34(1): 8-16. 
Bullard, J.E., McTainsh, G.H., 2003. Aeolian-fluvial interactions in dryland environments: examples, concepts and Australia case study. Progress in Physical Geography, 27(4): 471-501.

Burley, S.D., 1984. Patterns of Diagenesis in the Sherwoods Sandstone Group (Triassic), United Kingdom. Clay Minerals, 19: 403-440.

Cheel, R.J., Middleton, G.V., 1986. Horizontal laminae formed under upper flow regime plane bed conditions. The Journal of Geology, 94: 489-504.

Cooke, R.U., Warren, A., Goudie, A., 1993. Desert Geomorphology. UCL Press, London.

Cowan, G., 1993. Identification and significance of aeolian deposits within the dominantly fluvial Sherwood Sandstone Group of the East Irish Sea Basin UK. In: C.P. North, D.J. Prosser (Eds.), Geological Society, London, Special Publications. Characterization of Fluvial and Aeolian Reservoirs, pp. 231-245.

Dalrymple, R.W., Rhodes, R.N., 1995. Estuarine Dunes and Bars. In: G.M.E. Perillo (Ed.), Developments in sedimentology. Elsevier, pp. 359-422.

Dickerson, R.P., Forman, A., Liu, T., 2013. Co-development of alluvial fan surfaces and arid botanical communities, Stonewall Flat, Nevada, USA. Earth Surface Processes and Landforms, 38(10): 1083-1101.

Doornenbal, J.C., Stevenson, A.G. (Eds.), 2010. Petroleum Geological Atlas of the Southern Permian Basin Area. EAGE Publications, Houten, 1-342 pp.

Fisher, J.A., Nichols, G.J., Waltham, D.A., 2007. Unconfined flow deposits in distal sectors of fluvial distributary systems: Examples from the Miocene Luna and Huesca Systems, northern Spain. Sedimentary Geology, 195(1-2): 55-73.

Fossen, H., Schultz, R.A., Shipton, Z.K., Mair, K., 2007. Deformation bands in sandstone: a review. Journal of the Geological Society, 164(4): 755-769.

Gaunt, G.D., 1994. The Geology of the country around Goole, Doncaster and the Isle of Axholme. Memoir of the Geological Survey of Great Britain, sheet 79 and 88 (England and Wales). H.M.S.O., London.

Ghazi, S., Mountney, N.P., 2009. Facies and architectural element analysis of a meandering fluvial succession: The Permian Warchha Sandstone, Salt Range, Pakistan. Sedimentary Geology, 221(1-4): 99-126.

Ghinassi, M., 2011. Chute channels in the Holocene high-sinuosity river deposits of the Firenze plain, Tuscany, Italy. Sedimentology, 58(3): 618-642.

Gibling, M.R., 2006. Width and Thickness of Fluvial Channel Bodies and Valley Fills in the Geological Record: A Literature Compilation and Classification. Journal of Sedimentary Research, 76(5): 731-770.

Graf, W.L., 1988. Fluvial processes in dryland rivers. Springer-Verlag New York. 
Gran, K., Paola, C., 2001. Riparian vegetation controls on braided stream dynamics. Water Resources Research, 37(12): 3275-3283.

Gray, J., 2014. Petroleum prospectivity of the principal sedimentary basins on the United Kingdom Continental Shelf. Promote UK 2015. 80 pp.

Green, P.F., 1989. Thermal and tectonic history of the East Midlands shelf (onshore UK) and surrounding regions assessed by apatite fission track analysis. Journal of the Geological Society, 146(5): 755-773.

Grenfell, M., Aalto, R., Nicholas, A., 2012. Chute channel dynamics in large, sand-bed meandering rivers. Earth Surface Processes and Landforms, 37(3): 315-331.

Harvey, A., 2011. Dryland Alluvial Fans. In: D.S.G. Thomas (Ed.), Arid Zone Geomorphology. John Wiley \& Sons, Ltd, Chichester, pp. 333-371.

Holloway, S., Milodowski, A.E., Strong, G.E., Warrington, G., 1989. The Sherwood Sandstone Group (Triassic) of the Wessex Basin, southern England. Proceedings of the Geologists' Association, 100(3): 383-394.

Hough, E., Pearce, J.M., Kemp, S.J., Williams, G.M., 2006. An investigation of some sediment-filled fractures within redbed sandstones of the UK. Proceedings of the Yorkshire Geological and Polytechnic Society, 56(1): 41-53.

Hounslow, M.W., Ruffell, A.H., 2006. Triassic - seasonal rivers, dusty deserts and salty lakes. In: P.J. Brenchley, P.F. Rawson (Eds.), The Geology of England and Wales. Geological Society of London, London, pp. 295-324.

Howard, A.S., Warrington, G., Carney, J.N., Ambrose, K.A., Young, S.R., Pharoah, T.C., Cheney, C.S., 2009. Geology of the Nottingham district. Memoir of the British Geological Survey, Sheet 126 (England and Wales). British Geological Survey, Nottingham.

Huang, H.Q., Nanson, G.C., 1998. The influence of bank strength on channel geometry: an integrated analysis of some observations. Earth Surface Processes and Landforms, 23(10): 865-876.

Jeans, C.V., 2006. Clay mineralogy of the Permo-Triassic strata of the British Isles: onshore and offshore. Clay Minerals, 41(1): 309-354.

Jones, N.S., Ambrose, K., 1994. Triassic sandy braidplain and aeolian sedimentation in the Sherwood Sandstone Group of the Sellafield area, west Cumbria. Proceedings of the Yorkshire Geological and Polytechnic Society, 50(1): 61-76.

Kent, P., Gaunt, G.D., Wilson, V., 1980. British regional geology: Eastern England from the Tees to the Wash. H.M.S.O., London.

Kitching, R., Shearer, T.R., Shedlock, S.L., 1977. Recharge to Bunter Sandstone determined from Lysimeters. Journal of Hydrology, 33: 217-232. 
Kostaschuk, R.A.Y., Villard, P., 1996. Flow and sediment transport over large subaqueous dunes: Fraser River, Canada. Sedimentology, 43(5): 849-863.

Lee, J.R., Wakefield, O.J.W., Phillips, E., Hughes, L., 2015. Sedimentary and structural evolution of a relict subglacial to subaerial drainage system and its hydrogeological implications: an example from Anglesey, north Wales, UK. Quaternary Science Reviews, 109(0): 88-110.

Leeder, M.R., Hardman, M., 1990. Carboniferous geology of the Southern North Sea Basin and controls on hydrocarbon prospectivity. Geological Society, London, Special Publications, 55(1): 87-105.

Lesemann, J.-E., Piotrowski, J.A., Wysota, W., 2010. "Glacial curvilineations”: New glacial landforms produced by longitudinal vortices in subglacial meltwater flows. Geomorphology, 120(3-4): 153-161.

Lewin, J., Ashworth, P.J., 2014. Defining large river channel patterns: Alluvial exchange and plurality. Geomorphology, 215(0): 83-98.

McKie, T., Williams, B., 2009. Triassic palaeogeography and fluvial dispersal across the northwest European Basins. Geological Journal, 44(6): 711-741.

McKinley, J.M., Atkinson, P.M., Lloyd, C.D., Ruffell, A.H., Worden, R.H., 2011. How Porosity and Permeability Vary Spatially With Grain Size, Sorting, Cement Volume, and Mineral Dissolution In Fluvial Triassic Sandstones: The Value of Geostatistics and Local Regression. Journal of Sedimentary Research, 81(12): 844-858.

McKinley, J.M., Ruffell, A.H., Worden, R.H., 2013. An integrated stratigraphic, petrophysical, geochemical and geostatistical approach to the understanding of burial diagenesis: Triassic Sherwood Sandstone Group, South Yorkshire, UK. In: S. Morad, J.M. Ketzer, L.F. De Ros (Eds.), Linking Diagenesis to Sequence Stratigraphy of Sedimentary Rocks. International Association of Sedimentologists Special Publications, pp. 231255.

Meadows, N.S., Beach, A., 1993a. Controls on reservoir quality in the Triassic Sherwood Sandstone of the Irish Sea. Geological Society, London, Petroleum Geology Conference series, 4: 823-833.

Meadows, N.S., Beach, A., 1993b. Structural and climatic controls on facies distribution in a mixed fluvial and aeolian reservoir: the Triassic Sherwood Sandstone in the Irish Sea. Geological Society, London, Special Publications, 73(1): 247-264.

Miall, A.D., 1977. A review of the braided-river depositional environment. Earth-Science Reviews, 13(1): 1-62.

Miall, A.D., 1988. Architectural elements and bounding surfaces in fluvial deposits: anatomy of the Kayenta formation (lower jurassic), Southwest Colorado. Sedimentary Geology, 55(3-4): 233-262. 
Miall, A.D., 1996. The geology of fluvial deposits: Sedimentary facies, basin analysis, and petroleum geology. Springer Berlin, $582 \mathrm{pp}$.

Miall, A.D., 2014. Fluvial depositional systems. Springer, Switzerland, 316 pp.

Mountney, N.P., Thompson, D.B., 2002. Stratigraphic evolution and preservation of aeolian dune and damp/wet interdune strata: an example from the Triassic Helsby Sandstone Formation, Cheshire Basin, UK. Sedimentology, 49(4): 805-833.

Nemec, W., Postma, G., 2009. Quaternary Alluvial Fans in Southwestern Crete: Sedimentation Processes and Geomorphic Evolution, Alluvial Sedimentation. Blackwell Publishing Ltd., pp. 235-276.

Newell, A.J., 2006. Calcrete as a source of heterogeneity in Triassic fluvial sandstone aquifers (Otter Sandstone Formation, SW England) In: R.D. Barker, J.H. Tellam (Eds.), Fluid Flow and Solute Movement in Sandstones: The Offshore UK Permo-Triassic Red Bed Sequence. Geological Society of London Special Publications, London, pp. 119-127.

Nichols, G., 2009. Sedimentology and stratigraphy. Wiley-Blackwell, Chichester, West Sussex, $419 \mathrm{pp}$.

Olsen, H., 1988. The architecture of a sandy braided-meandering river system: an example from the Lower Triassic Soiling Formation (M. Buntsandstein) in W-Germany. Geologische Rundschau, 77(3): 797-814.

Peakall, J., Ashworth, P.J., Best, J.L., 2007. Meander-Bend Evolution, Alluvial Architecture, and the Role of Cohesion in Sinuous River Channels: A Flume Study. Journal of Sedimentary Research, 77(3): 197-212.

Røe, S.-L., Hermansen, M., 2006. New aspects of deformed cross-strata in fluvial sandstones: Examples from Neoproterozoic formations in northern Norway. Sedimentary Geology, 186(3-4): 283-293.

Rust, B.R., 1972. Structure and process in a braided river. Sedimentology, 18(3-4): 221-245.

Sadler, S.P., Kelly, S.B., 1993. Fluvial processes and cyclicity in terminal fan deposits: an example from the Late Devonian of southwest Ireland. Sedimentary Geology, 85(1-4): 375-386.

Schmid, S., Worden, R.H., Fisher, Q.J., 2004. Diagenesis and reservoir quality of the Sherwood Sandstone (Triassic), Corrib Field, Slyne Basin, west of Ireland. Marine and Petroleum Geology, 21(3): 299-315.

Smedley, P.L., Edmunds, W.M., 2002. Redox patterns and trace-element behavior in the East Midlands Triassic Sandstone aquifer, UK. Ground Water, 40(1): 44-58.

Smith, D.B., Harwood, G.M., Pattison, J., Pettigrew, T.H., 1974. A correlation of Permian rocks in the British Isles. Geological Society Special Report, 5: 45. 
Stanistreet, I.G., Stollhofen, H., 2002. Hoanib River flood deposits of Namib Desert interdunes as analogues for thin permeability barrier mudstone layers in aeolianite reservoirs. Sedimentology, 49(4): 719-736.

Steel, R.J., Thompson, D.B., 1983. Structures and textures in Triassic braided stream conglomerates ('Bunter' Pebble Beds) in the Sherwood Sandstone Group, North Staffordshire, England. Sedimentology, 30(3): 341-367.

Wakefield, O.J.W., Mountney, N.P., 2013. Stratigraphic architecture of back-filled incisedvalley systems: Pennsylvanian-Permian lower Cutler beds, Utah, USA. Sedimentary Geology, 298(0): 1-16.

Walker, R.G., Cant, D.J., 1984. Sandy fluvial systems. In: R.G. Walker (Ed.), Facies Models 2nd Ed. Geoscience Canada Reprint Series, pp. 71-89.

Walling, D.E., He, Q., 1998. The spatial variability of overbank sedimentation on river floodplains. Geomorphology, 24: 209-223.

Warrington, G., 1970. The stratigraphy and palaeontology of the 'Keuper' Series of the central Midlands of England. Quarterly Journal of the Geological Society, 126(1-4): 183-223.

Warrington, G., Audley-Charles, M.G., Elliott, R.E., Evans, W.B., Ivimey-Cook, H.C., Kent, P.G., Robinson, P.L., Shotton, F.W., Taylor, F.M., 1980. A correlation of Triassic rocks in the British Isles. Special Report of the Geological Society of London, 13: 78.

Wills, L.J., 1970. The Triassic succession in the central Midlands in its regional setting. Quarterly Journal of the Geological Society, 126(1-4): 225-283.

Ziegler, P.A., 1988. Evolution of the Arctic-North Atlantic and the Western Tethys. American Association of Petroleum Geologists' Memoir, 43: 1-198.

\section{Figure Captions}

Fig. 1 - Map depicting surface expression of the SSG (highlighted in yellow) with topographic highs (areas of non-deposition) during the Triassic. Note dashed lines that delineate informal geographic divisions of the Sherwood Sandstone Group into eastern, western, central and southern areas.

Fig. 2 - Location map. A) Map of the northern England depicting the surface crop of the Sherwood Sandstone Group. B) Aerial photographs of Styrrup Quarry. DiGMapGB data, BGS (C) NERC. Contains Ordnance Survey data (c) Crown Copyright and database rights 2015

Fig. 3 - Example stratigraphic columns of the SSG. A) Example from the western SSG around Runcorn. B) Eastern SSG example for the area around Styrrup Quarry, note the nomenclature change and removal of the Lenton Sandstone Formation from the Group (see Ambrose et al., 2014). Zech. Grp. = Zechstein Group, Rox. F. = Roxby Formation, Broth. F. = Brotherton Formation, Edling. F. = Edlington Formation. 
Fig. 4 - Panel data set from Styrrup Quarry, see Fig. 1b for location. A) Panels depicted as planar 2D sections; palaeocurrent information portrayed from collection points. B) Panel depicted in 3D form to match orientation outcrop, note north direction.

Fig. 5 - Sedimentary logs from Styrrup Quarry. Log positions are depicted on Fig. 2.

Fig. 6 - Photographic example of lithofacies. A) Pebbly sandstone (Spb), B) Trough crossbedding (St) and planar crossbedded sandstone (Sp), C) Low-angle crossbedded sandstone, note mud intraclasts (SI), D) Upper plane beds (Sh1), E) Horizontally laminated sandstone (Sh2), F) Massive Sandstone (Sm), G) Multiple sets of ripple cross-laminated sandstone $(\mathrm{Sr}), \mathrm{H})$ Silty sandstone $(\mathrm{FI})$ overlain by erosive surfaces with pebble lags.

Fig. 7 - Examples of larger observed mud intraclasts. A) Multiple mud cobbles at base of facies St, B) Larger $>30 \mathrm{~cm}$ wide highly weathered mud clast, C) Broken mud clast at base of facies Sp.

Fig. 8 - Photograph example of a chute channel element $(A)$ and diagrammatic interpretation (B).

Fig. 9 - Conceptual palaeogeographic model for the Styrrup Quarry locality.

\section{Table Caption}

Table 1 - Identified lithofacies for the Sherwood Sandstone Group at Styrrup Quarry.

Table 2 - Identified architectural elements for the Sherwood Sandstone Group at Styrrup Quarry. 


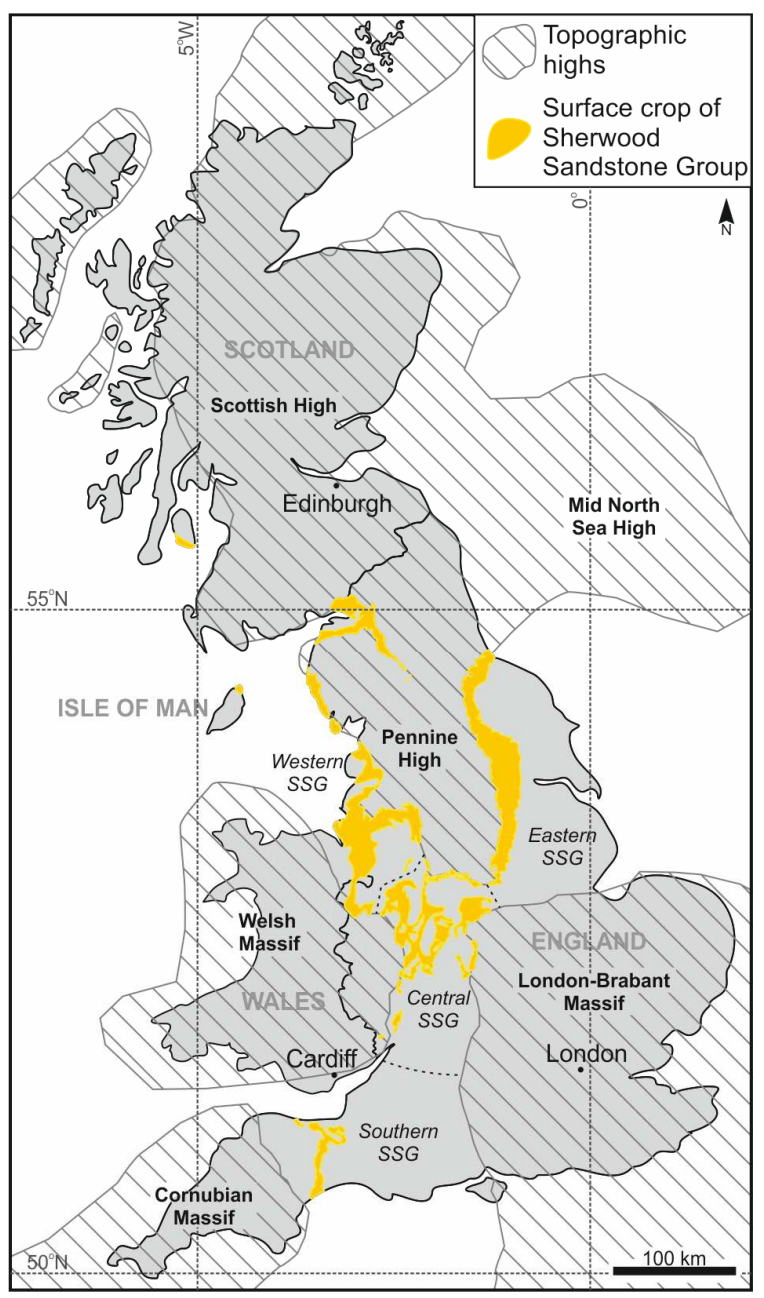

Figure 1 

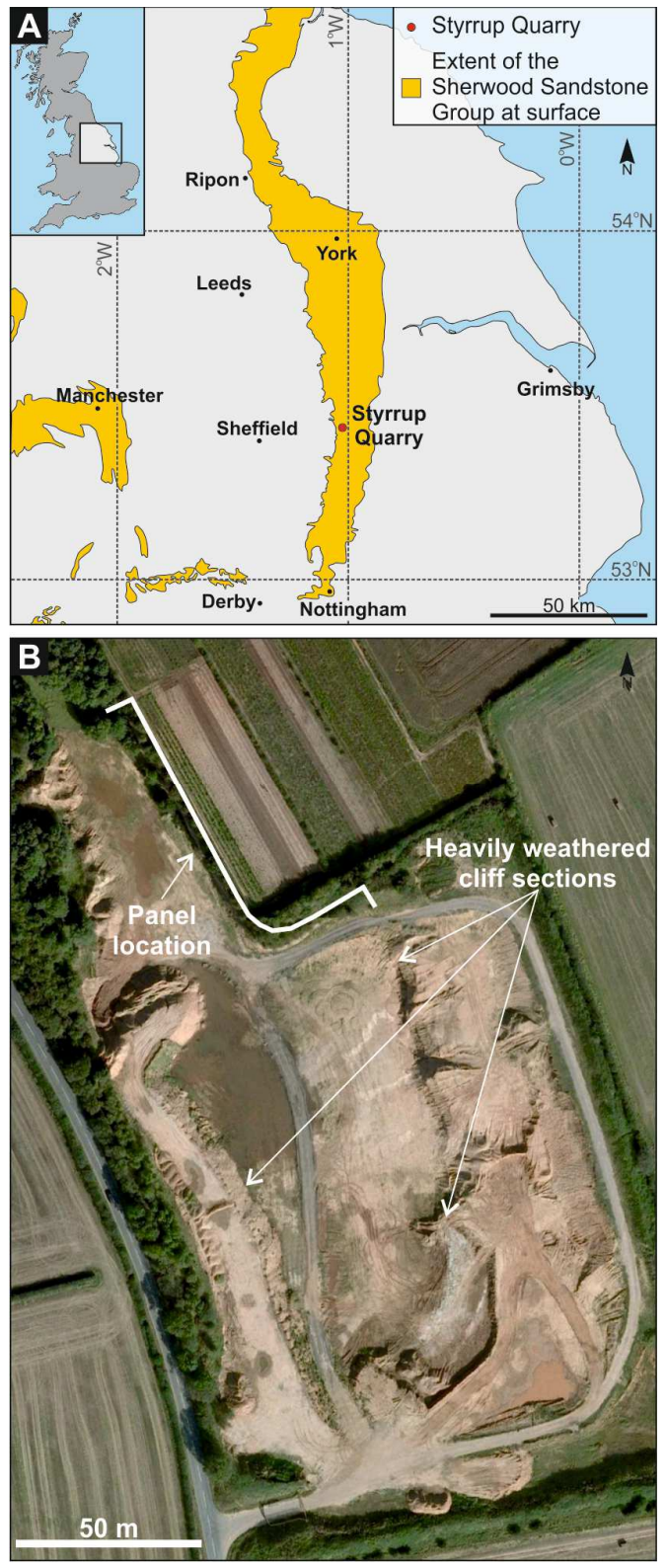

Figure 2 


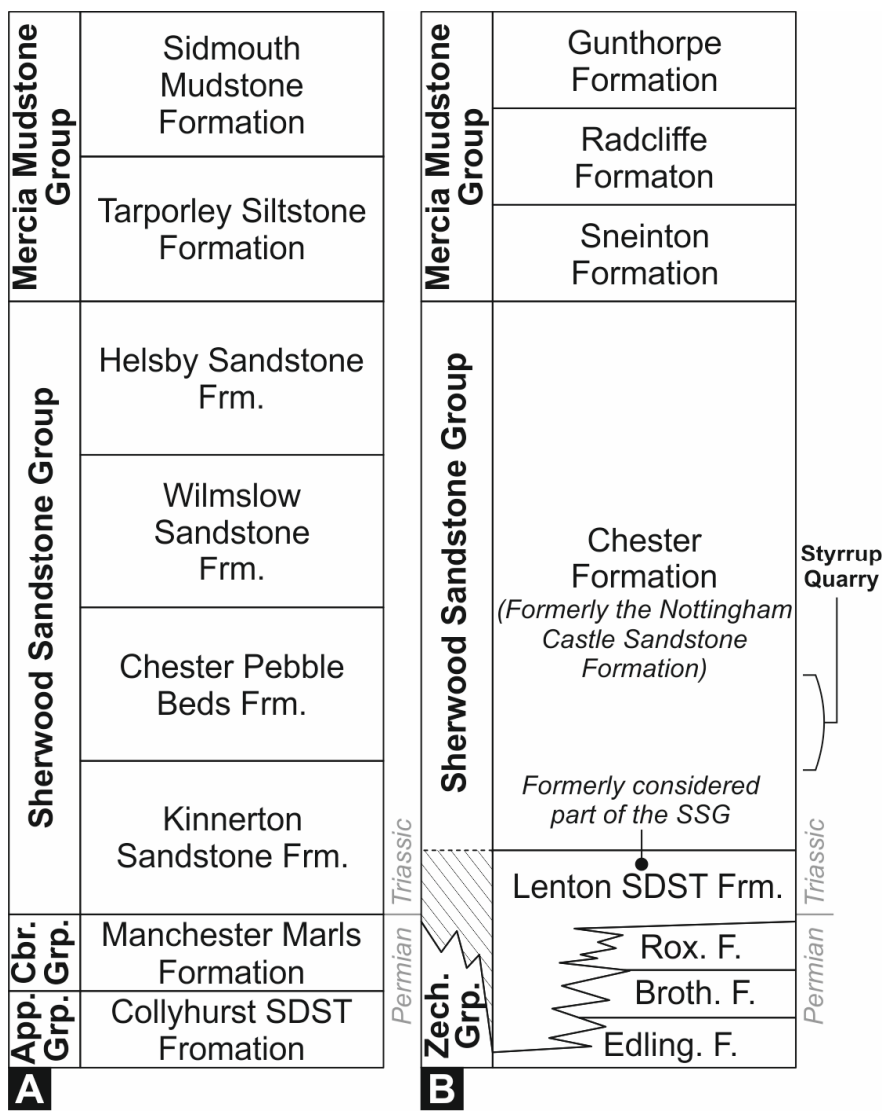

Figure 3 


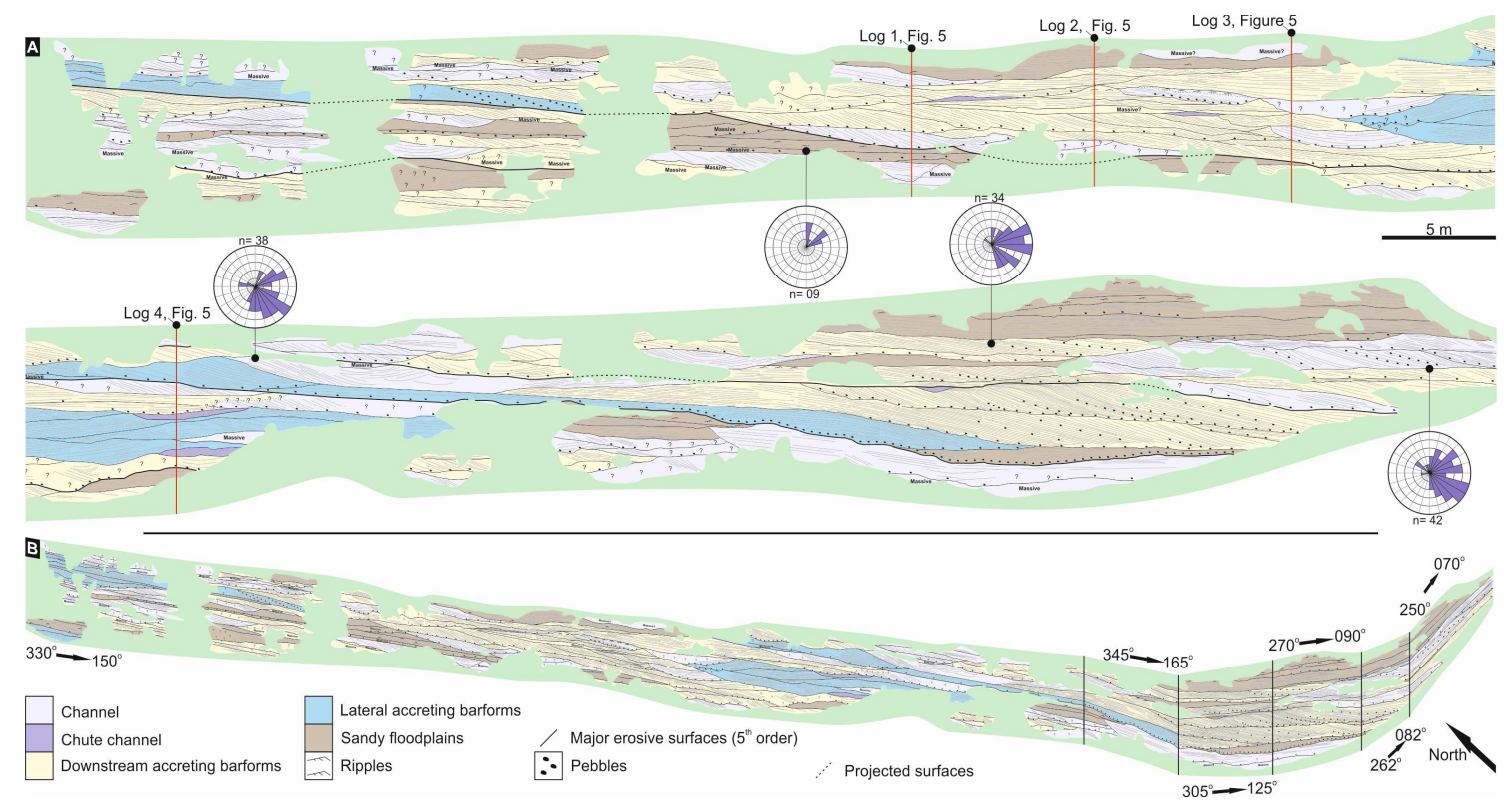

Figure 4 

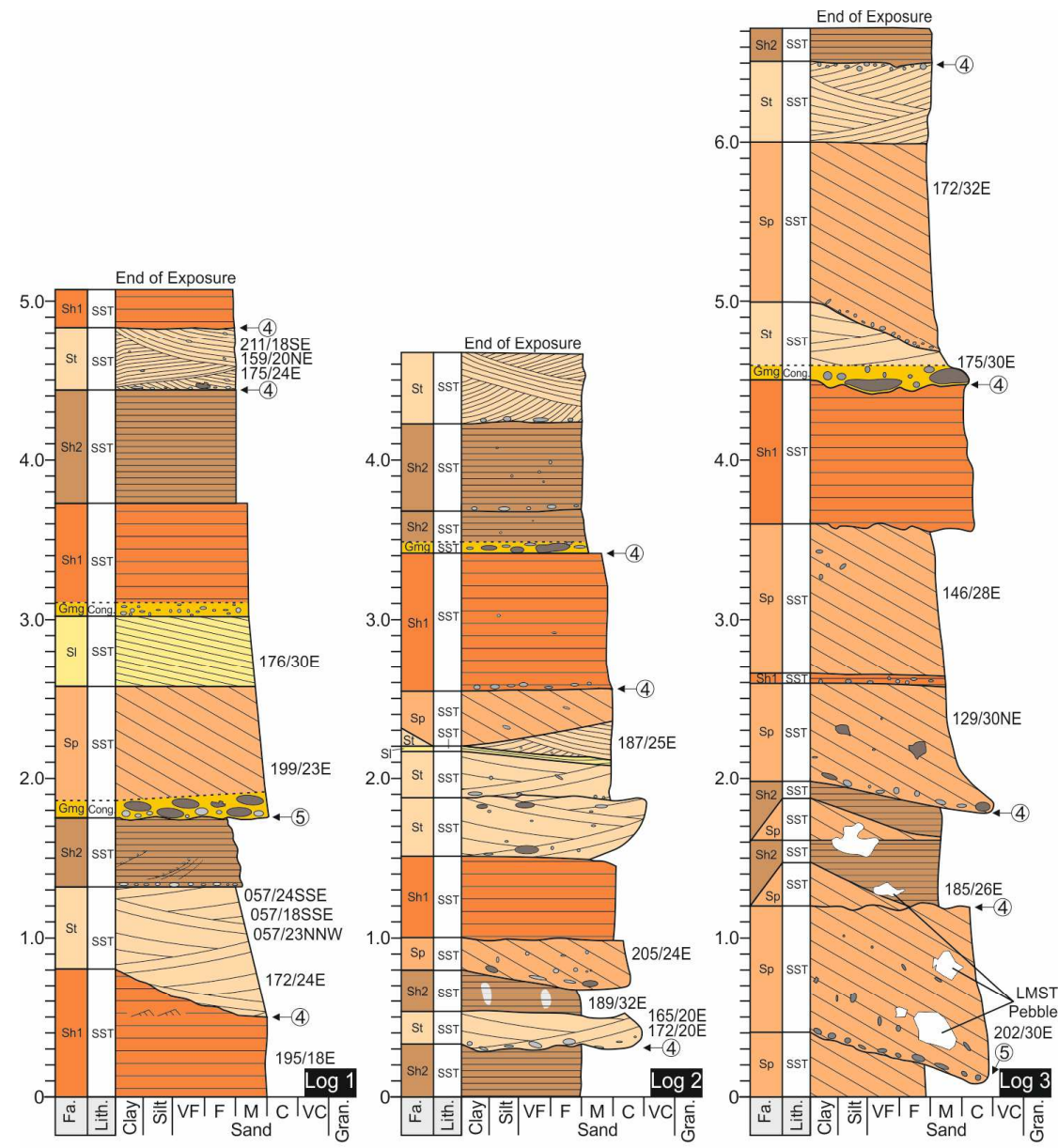

Matrix-supported conglomerates (Gmg)

Planar crossbedded SST (Sp)

Trough crossbedded SST (St)

Horizontally bedded SST (Sh1)

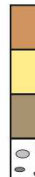

Horizontally laminated SST (Sh2)

Low-angle crossbedded SST (SI)

Laminated Mudstone (FI)

$\because$ Pebbles

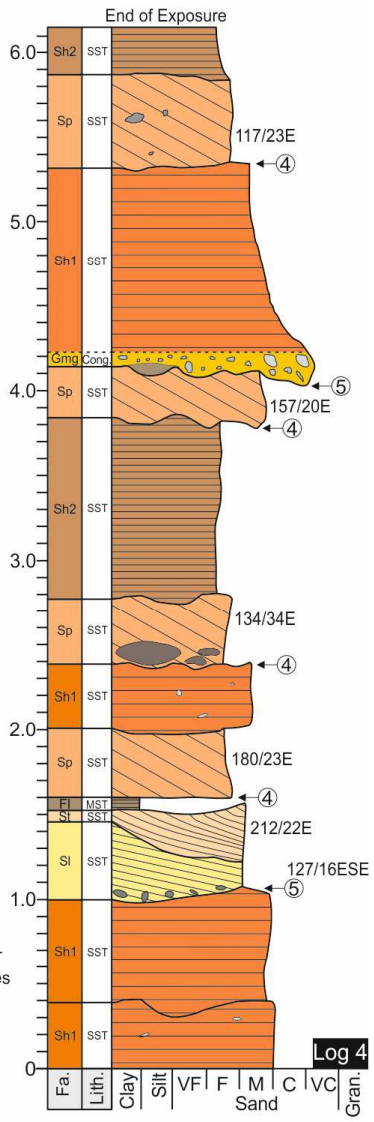

Mottling

- Transitional boundary

-5) Bounding surface number (only 4 and 5 shown)

Figure 5 

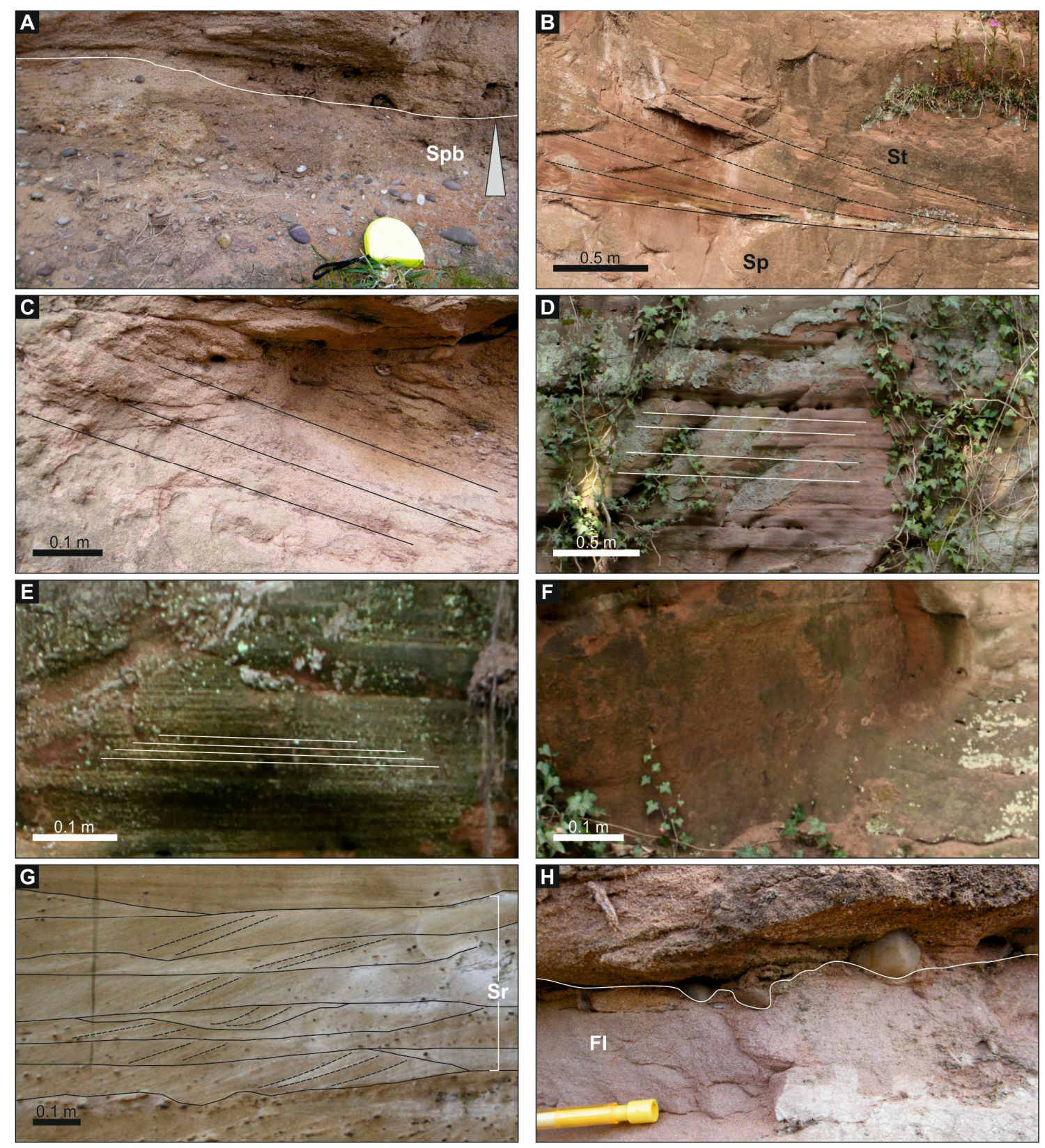

Figure 6 

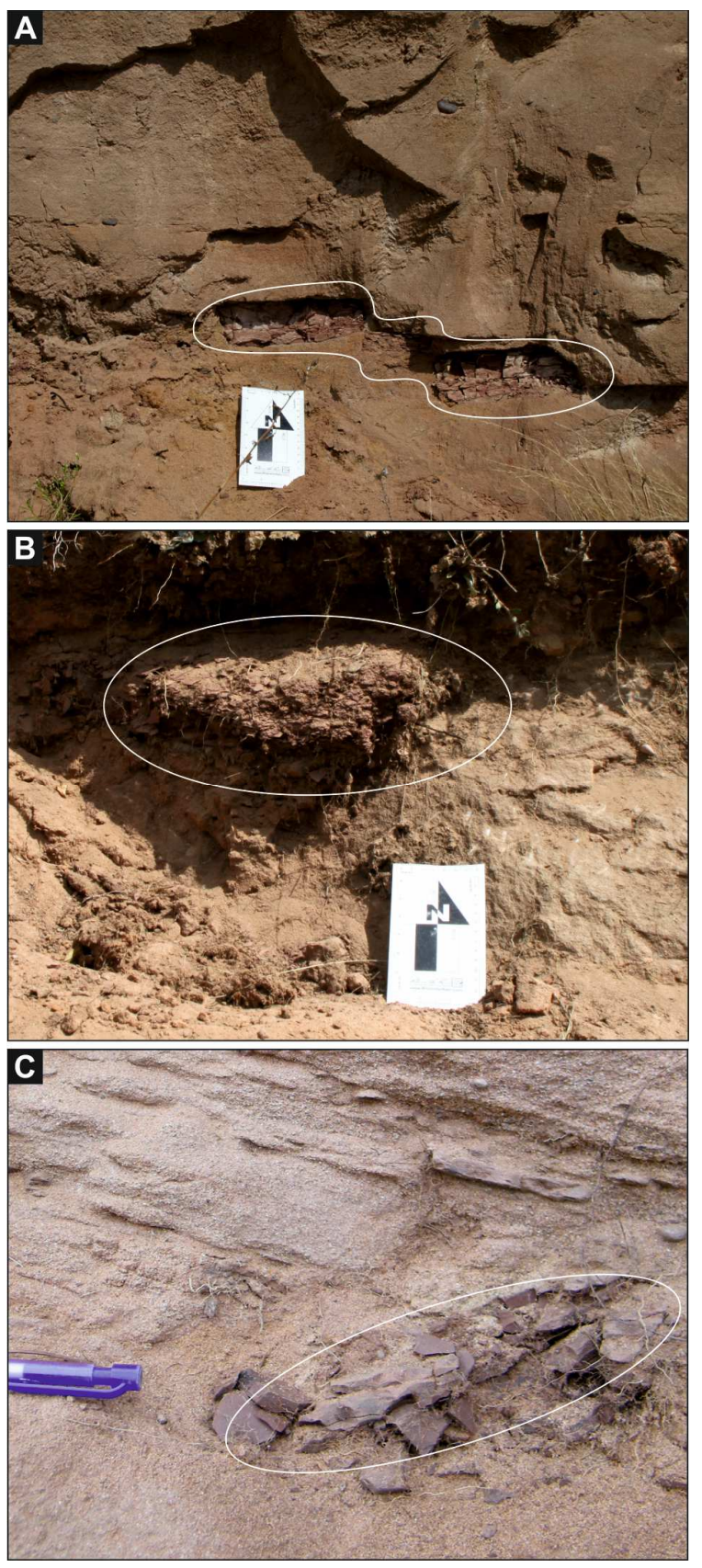

Figure 7 


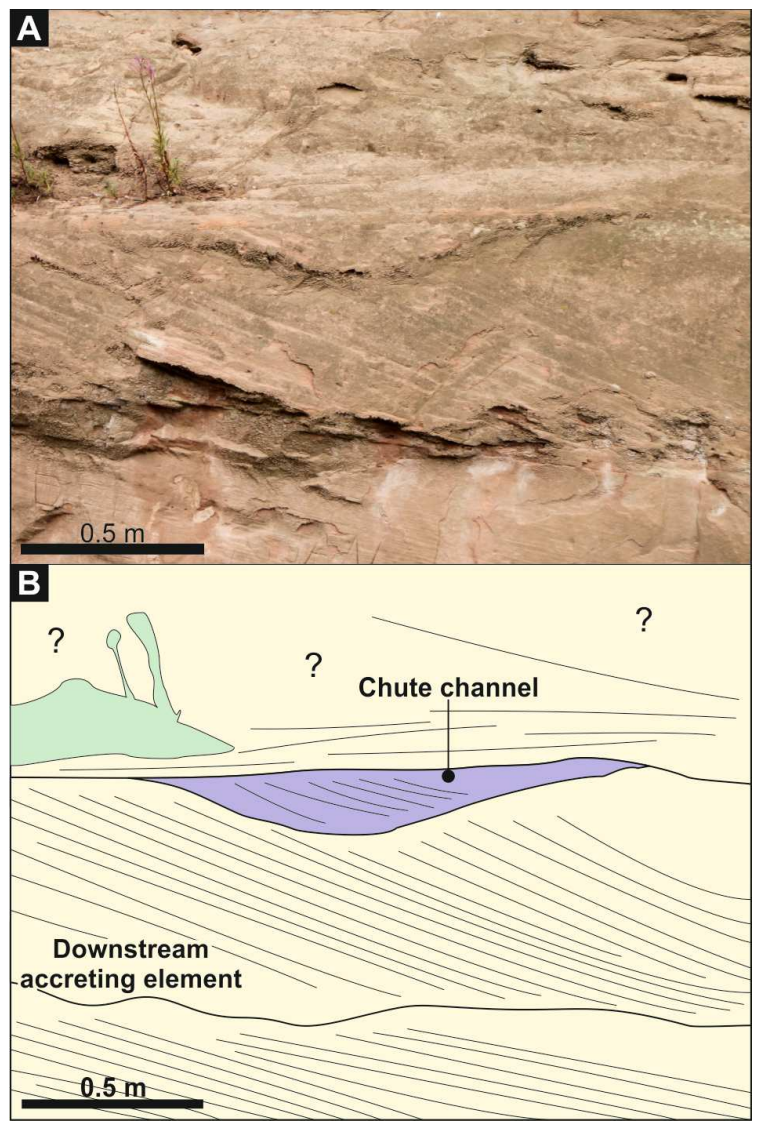

Figure 8 


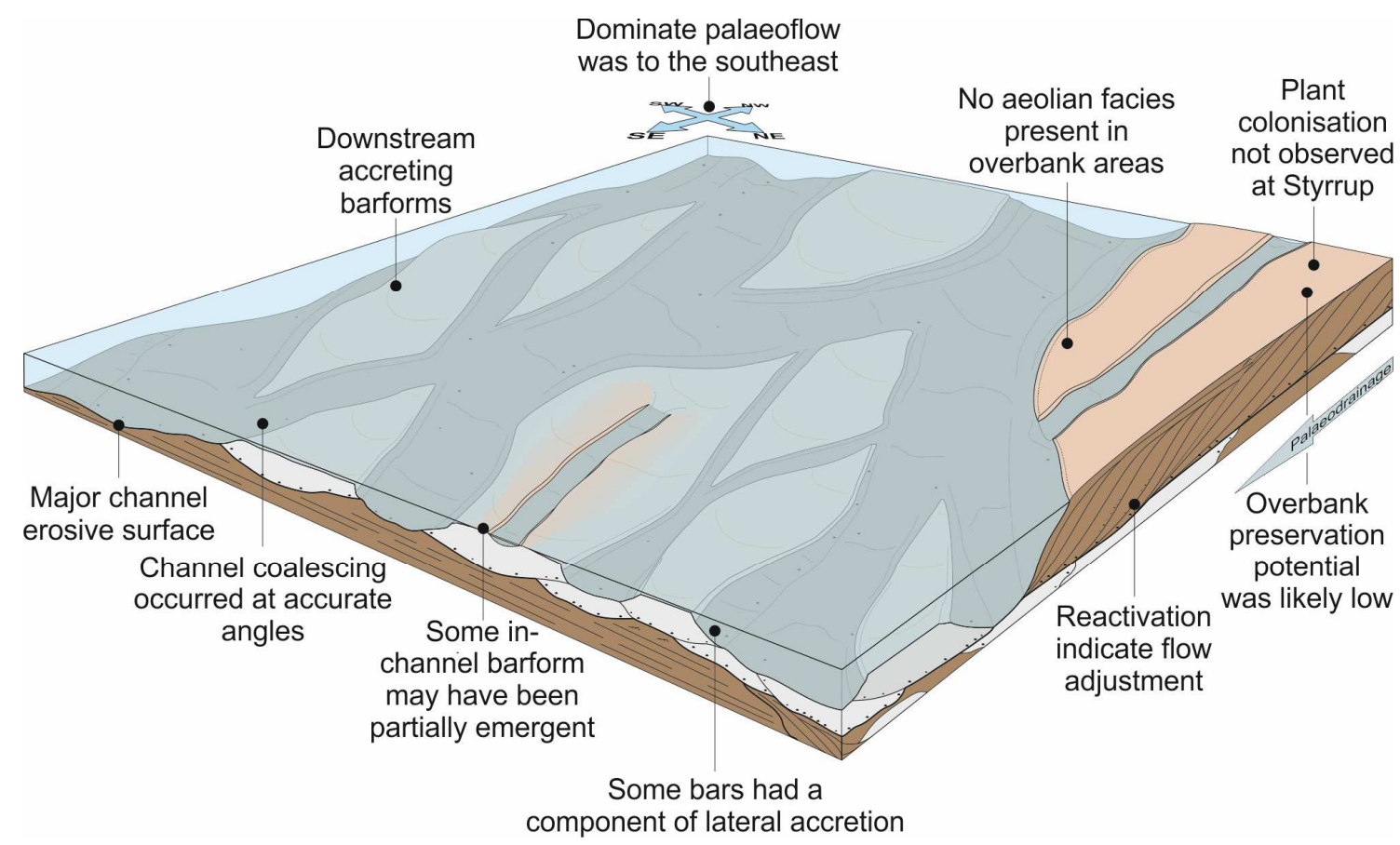

Figure 9 
$\mathrm{Spb}$ Sand, medium- to coarse grained, Normally graded - sometimes weakly Channel lag deposits with abundant pebbles ( $>20 \%$ by vol.) (Fig. 4 a)

$\mathrm{Sp}$ Sand, medium- to coarse grained, Planar crossbeds arranged in single or Migration of single / multiple 2D bedforms sometimes pebbly multiple sets (Fig. 4b)

St Sand, medium- to coarse grained, Trough crossbeds arranged in single Migration of single/multiple 3D bedforms sometimes pebbly or multiple sets (Fig. $4 \mathrm{~b}$ )

SI Sand, fine - to coarse-grained, Low-angle crossbedding $=<15^{\circ}$ (Fig. Migration of humpback duneforms (cf. Kostaschuk isolated pebbles 4c) and Villard, 1996)

Sh1 Sand, medium- to coarse-grained, Horizontal bedding/lamination, parting Upper plane beds (upper flow regime) isolated pebbles lineation (Fig. 4d)

Sh2 Sand, very-fine- to fine-medium- Horizontal lamination, rare instance of Settling from suspension grained cm scale bedding (Fig. 4e)

$\mathrm{Sr}$ Sand, fine- to medium-grained Ripple cross-lamination (Fig. 4g) Migration of rippleforms

Sm Sand, fine- to coarse-grained, Structureless - Massive (Fig. 4f) Gravity flow deposit isolated pebbles

FI Silty sand (very fine) rare instances Fine lamination, often contains crude Non-channelised flow and settling from suspension of mud rippleforms (Fig. 4h)

\section{Table 1}




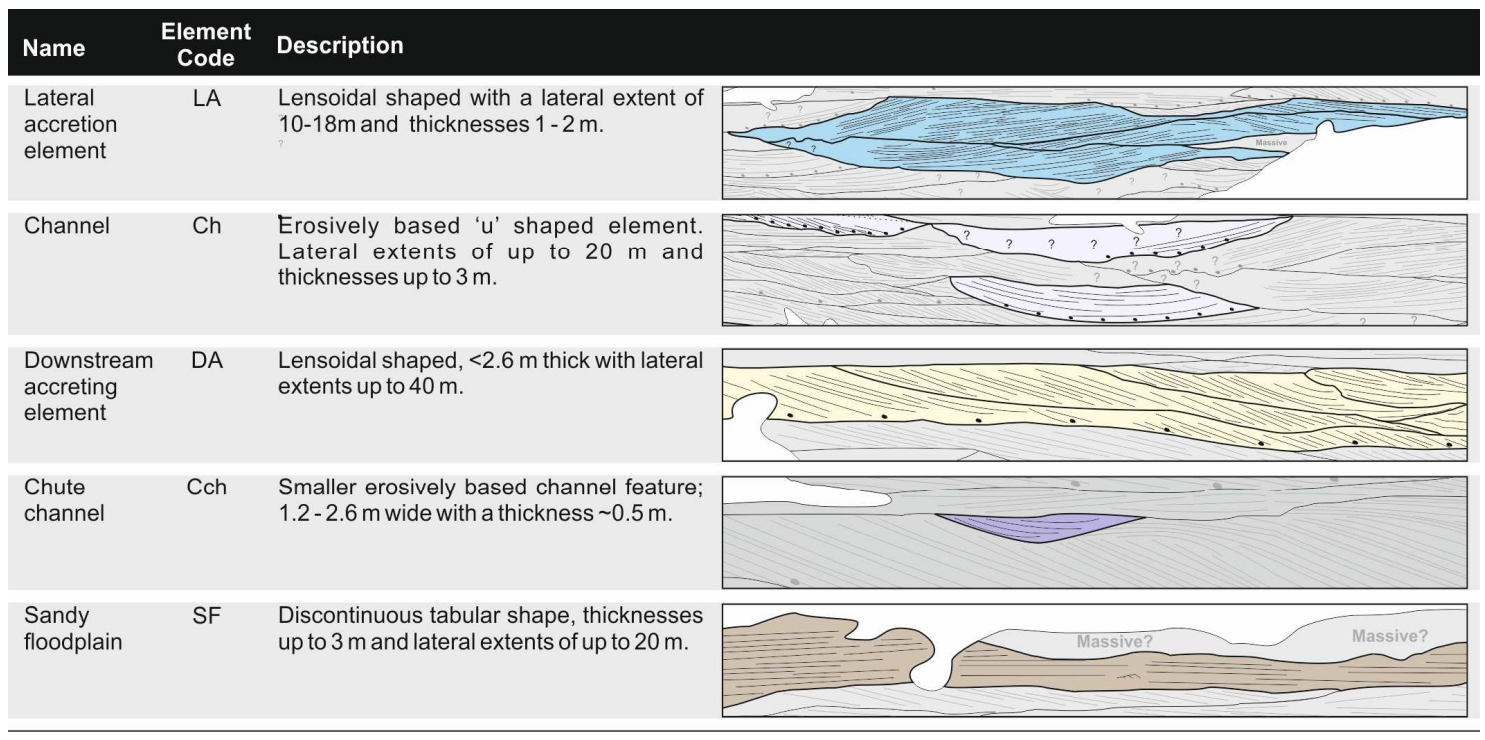

Table 2 